\title{
PERLINDUNGAN KONSUMEN MELALUI SERTIFIKASI DAN LABELISASI HALAL ATAS INDUSTRI RUMAH TANGGA PANGAN
}

\author{
Leliya \\ Fakultas Syariah dan Ekonomi Islam \\ Institut Agama Islam Negeri Syekh Nurjati Cirebon \\ email: leliya12@yahoo.co.id
}

\begin{abstract}
Cirebon City Many Household Food Industries hereinafter called small and medium enterprises engaged in traditional food field. On the other hand, the above conditions and phenomena can result in the position of business actors and consumers becoming unbalanced and consumers are in a weak position. Consumers are the object of business activities to profit maximally by business actors. This research uses qualitative approach. The research results of the research in the form of consumer protection through certification and the halal label on Household Food Industry at the Department of Trade, Cooperatives, Small and Medium Enterprises of Cirebon City through certification and halal label is the issuance of Household Food Production Certificate issued by the Dinas Kesehatan City of Cirebon. Another form of consumer protection is the Consumer Dispute Settlement Agency of Cirebon City for consumers who feel harmed by the producers and willing to resolve consumer disputes. The role of Trade, Cooperatives, Small and Medium Enterprises of Cirebon City in certification and halal label on household food industry is to facilitate Small and Medium Enterprises and the general public who have food production business to recruit Small and Medium Industry in area of Cirebon City who wishes to get a halal certificate for free.
\end{abstract}

Keywords: Protection, Consumer, Halal Certification and Halal Label.

\begin{abstract}
Abstrak
Kota Cirebon banyak Industri Rumah Tangga Pangan untuk selanjutnya disebut perusahaan kecil dan menengah yang bergerak di bidang makanan tradisional. Di sisi lain, kondisi dan fenomena di atas dapat mengakibatkan kedudukan pelaku usaha dan konsumen menjadi tidak seimbang dan konsumen berada pada posisi yang lemah. Konsumen menjadi objek aktivitas bisnis untuk meraup keuntungan yang sebesar-besarnya oleh pelaku usaha. Penelitian ini menggunakan pendekatan kualitatif. Adapun hasil penelitian adalah bentuk perlindungan konsumen melalui sertifikasi dan label halal atas Industri Rumah Tangga Pangan pada Dinas Perdagangan, Koperasi, Usaha Kecil dan Menengah Kota Cirebon melalui sertifikasi dan label halal adalah dengan dikeluarkannya Sertifikat Produksi Pangan Industri Rumah Tangga yang dikeluarkan oleh Dinas Kesehatan Kota Cirebon. Bentuk lain perlindungan terhadap konsumen adanya Badan Penyelesaian Sengketa Konsumen Kota Cirebon untuk konsumen yang merasa dirugikan oleh produsen dan berkehendak untuk menyelesaikan sengketa konsumen. Peran Dinas Perdagangan, Koperasi, Usaha Kecil dan Menengah Kota Cirebon dalam sertifikasi dan label halal atas industri rumah tangga pangan adalah memfasilitasi Industri Kecil Menengah dan masyarakat umum yang mempunyai usaha produksi pangan untuk merekruit Industri Kecil Menengah di wilayah Kota Cirebon yang berkeinginan memperoleh sertifikat halal secara gratis.
\end{abstract}

Kata Kunci: Perlindungan, Konsumen, Sertifikasi dan Label Halal. 


\section{PENDAHULUAN}

Menurut Ahmadi Miru dan Sutarman Yodo ${ }^{1}$ Undang-Undang Nomor 8 Pasal 1 ayat (1) Tahun 1999 tentang perlindungan konsumen disebutkan bahwa perlindungan konsumen adalah segala upaya yang menjamin adanya kepastian hukum untuk memberi perlindungan kepada konsumen. Kepastian hukum untuk melindungi hak-hak konsumen, yang diperkuat melalui undangundang khusus, memberikan harapan agar pelaku usaha tidak lagi sewenang-wenang yang selalu merugikan hak konsumen. Dengan adanya Undang-Undang Nomor 8 Tahun 1999 tentang Perlindungan Konsumen beserta perangkat hukum lainnya, konsumen memiliki hak dan posisi yang berimbang, dan mereka pun bisa menggugat atau menuntut jika ternyata hakhaknya telah dirugikan atau dilanggar oleh pelaku usaha.

Seperti halnya Kota Cirebon banyak Industri Rumah Tangga Pangan untuk selanjutnya disebut IRTP atau perusahaan kecil dan menengah yang bergerak di bidang makanan tradisional dalam kemasan atau camilan. Produsen makanan jajanan dalam kemasan tersebut masih banyak yang belum mencantumkan tanggal kadaluarsa dalam produknya. Tidak mencantumkan tanggal kadaluarsa dapat membahayakan bagi konsumen karena konsumen tidak akan tahu kapan makanan yang dikonsumsinya tersebut dalam kondisi akan kadaluarsa. Kasus ini juga melanggar Undang-Undang Nomor 8 Tahun 1999 tentang Perlindungan Konsumen yang mewajibkan produsen untuk mencantumkan tanggal kadaluarsa pada produk makanannya. Hal-hal yang merugikan konsumen tersebut bisa saja disebabkan karena kurangnya pengawasan dari Pemerintah serta badan-badan hukum seperti Kepolisian, BPOM, Dinas Perindustrian dan Perdagangan

\footnotetext{
${ }^{1}$ Ahmadi Miru dan Sutarman Yodo, Prinsipprinsip Perlindungan Hukum bagi Konsumen di Indonesia (Jakarta: PT. Raja Grafindo Persada, Jakarta, 2011), 1.
}

(Disperindag), dan Dinas Kesehatan (Dinkes).

Faktor utama yang menjadi kelemahan konsumen adalah tingkat kesadaran konsumen akan haknya masih rendah. Hal ini terutama disebabkan oleh rendahnya pendidikan konsumen. Oleh karena itu, Undang-Undang Nomor 8 Tahun 1999 tentang Perlindungan Konsumen dimaksudkan menjadi landasan hukum yang kuat bagi pemerintah dan lembaga perlindungan konsumen swadaya masyarakat untuk melakukan upaya pemberdayaan konsumen melalui pembinaan dan pendidikan konsumen. ${ }^{2}$

Produk yang belum mendapat sertifikat halal atau berlabel halal tidak berarti dinyatakan haram, tapi dinyatakan tidak terjamin kehalalannya Sertifikat halal diberikan bagi produk yang telah diaudit dan dan dinyatakan halal oleh Komisi Fatwa MUI, jadi bukan perusahaannya. Khusus untuk restoran, sertifikat halal dikeluarkan apabila seluruh produk yang disajikan di restoran tersebut telah dinyatakan halal (memiliki sertifikat halal).

Bagi konsumen, sertifikat halal memiliki beberapa fungsi. Pertama, terlindunginya konsumen muslim dari mengonsumsi pangan, obat- obatan dan kosmetika yang tidak halal; kedua, secara kejiwaan perasaan hati dan batin konsumen akan tenang; ketiga, mempertahankan jiwa dan raga dari keterpurukan akibat produk haram; dan keempat, akan memberikan kepastian dan perlindungan hukum.

Untuk itu maka penulis merasa perlu untuk mengkaji lebih dalam lagi mengenai pertama, bagaimanakah bentuk perlindungan konsumen melalui sertifikasi dan label halal atas industri rumah tangga pangan (IRTP) pada Dinas Perdagangan, Koperasi, Usaha Kecil dan Menengah Kota Cirebon? Dan kedua, bagaimana peran Dinas Perdagangan, Koperasi, Usaha Kecil

${ }^{2}$ Ahmad Yani dan Gunawan Wudjaya, Hukum Perlindungan Konsumen (Jakarta: Gramedia Pustaka Utama, 2000), 54. 
dan Menengah Kota Cirebon dalam sertifikasi dan label halal atas industri rumah tangga pangan (IRTP)?

\section{LITERATURE REVIEW}

Setelah penulis melakukan penelusuran untuk mengetahui berbagai hasil kajian dan penelitian terdahulu maka ditemukan berbagai judul hasil penelitian serupa yang telah dilakukan berkaitan dengan sertifikasi dan label halal pada Industri Rumah Tangga Pangan sebagai salah satu bentuk perlindungan konsumen, serta memahami bagaimana peran dari Dinas Perdagangan, Koperasi, Usaha Kecil dan Menengah Kota Cirebon dalam sertifikasi dan label halal atas industri rumah tangga pangan.

Pertama, KN. Sofyan Hasan (2015), Universitas Sriwijaya Palembang judul peelitian Pengawasan dan Penegakan Hukum terhadap Sertifikasi dan Label Halal Produk Pangan, pokok permasalahan dalam penelitian ini adalah bagaimana upaya penegakan hukum dan perlindungan hak konsumen terhadap sertifikasi dan label produk halal menurut UUPJH, serta faktorfaktor yang menyebabkan pelaku usaha menunda sertifikasi dan label produk halal atas produk-produk mereka.

Perbedaan dari penelitian terdahulu membahas tentang sertifikasi dan label halal pada Industri Rumah Tangga Pangan sebagai salah satu bentuk perlindungan konsumen, serta memahami bagaimana peran dari Dinas Perdagangan, Koperasi, Usaha Kecil dan Menengah Kota Cirebon dalam sertifikasi dan label halal atas industri rumah tangga pangan.

Kedua, Lindu Aji Saputro (2012), Universitas Sebelas Maret Surakarta judul penelitian Analisis Perlindungan Hukum dari Pemalsuan Sertifikasi dan Label Halal sebagai bentuk Legitimasi Kehalalan Produk di Indonesia, penelitian ini bertujuan untuk perlindungan hukum yang diberikan kepada konsumen dari pemalsuan sertifikasi dan label halal sebagai bentuk legitimasi kehalalan produk di Indonesia.
Perbedaan dari penelitian terdahulu membahas tentang sertifikasi dan label halal pada Industri Rumah Tangga Pangan sebagai salah satu bentuk perlindungan konsumen, serta memahami bagaimana peran dari Dinas Perdagangan, Koperasi, Usaha Kecil dan Menengah Kota Cirebon dalam sertifikasi dan label halal atas industri rumah tangga pangan.

Ketiga, Iwan Zainul Fuad (2010), Universitas Diponegoro judul Penelitian Kesadaran Hukum Pengusaha Kecil di Bidang Pangan dalam Kemasan terhadap Regulasi Sertifikasi Produk Halal, penelitian ini menunjukkan bahwa kesadaran hukum mereka sangat tinggi, namun dengan cara tidak melakukan proses sertifikasi (halal). Langkah yang mereka tempuh tersebut disebabkan oleh berbagai faktor, baik secara ekonomis (birokrasi biaya tinggi), yuridis (ketakutan akan sanksi), hingga kepercayaan (ketidakpercayaan terhadap sertifikasi halal dari MUI). Upaya peningkatan kesadaran hukum yang dilakukan pihak MUI Jawa Tengah sangat minim. Upaya yang dilakukan hanya bersifat preventif. Minimnya upaya tersebut terlihat dari tidak adanya ketentuan definitif menganai biaya sertifikasi yang berlaku secara universal (untuk semua level usaha), hingga profesionalitas MUI Jawa Tengah dalam menangani proses sertifikasi produk halal.

Perbedaan dari penelitian terdahulu membahas tentang sertifikasi dan label halal pada Industri Rumah Tangga Pangan sebagai salah satu bentuk perlindungan konsumen, serta memahami bagaimana peran dari Dinas Perdagangan, Koperasi, Usaha Kecil dan Menengah Kota Cirebon dalam sertifikasi dan label halal atas industri rumah tangga pangan.

\section{METODOLOGI PENELITIAN Pendekatan Penelitian}

Penelitian ini menggunakan pendekatan kualitatif, menginvestigasi dan memahami fenomena seperti apa yang terjadi mengapa terjadi dan bagaimana terjadinya, sekaligus memahami suatu situasi social, peristiwa, 
peran interaksi. Hal ini dikarenakan pada penelitian ini peneliti menggunakan berbagai sumber data, teori, metode, dan investigator agar informasi yang disajikan konsisten. Pengumpulan data dalam penelitian kualitatif kualitas riset sangat tergantung pada kualitas dan kelengkapan data yang dihasilkan. Pertanyan yang selalu dpperhatikan dalam pengumpulan data adalah apa, siapa, dimana, kapan, dan bagaimana. dalam penelitian ini digunakan teknik pengumpulan data yaitu wawancara, observasi dan analisis dokumen.

Dalam penelitian ini wawancara memegang peran yang sangat penting karena karena metode wawancara digunakan peneliti untuk mengumpulkan data dan memperoleh informasi. Analisis data, untuk dilakukan analisis peneliti perlu menangkap, mencatat menginterprestasikan dan menyajikan informasi. Pada penelitian ini tahap-tahap analisis data dilakukan dengan metode triangguilasi data.

\section{Fokus Penelitian}

Fokus penelitian yang dibahas dalam penelitian ini adalah perlindungan konsumen melalui sertifikasi dan label halal atas industri rumahtangga pangan (IRTP). Untuk menghindari terlalu meluasnya masalah yang dibahas maka fokus masalah penelitian dibatasi hanya sampai pada:

1. Bentuk perlindungan konsumen melalui sertifikasi dan label halal atas industri rumah tangga pangan (IRTP) pada Dinas Perdagangan, Koperasi, Usaha Kecil dan Menengah Kota Cirebon.

2. Peran Dinas Perdagangan, Koperasi, Usaha Kecil dan Menengah Kota Cirebon dalam sertifikasi dan label halal atas industri rumah tangga pangan (IRTP).

\section{Data dan Sumber Data Penelitian}

1. Data primer / empirik

Sumber ini diperoleh penulis dengan terjun langsung ke objek penelitian serta informasi-informasi yang didapat di lokasi penelitian.
Penelitian lapangan adalah penelitian dengan cara terjun langsung ke lapangan untuk memperoleh data yang diperlukan dengan jalan wawancara, yaitu pengumpulan data dengan melaksanakan tanya jawab langsung dengan responden yaitu Kepala Dinas Perdagangan, Koperasi, Usaha Kecil dan Menengah Kota Cirebon, Kepala Dinas Kesehatan Kota Cirebon, Ketua Badan Penyelesaian Sengketa Konsumen (BPSK) Kota Cirebon, Majelis Ulama Indonesia Kota (MUI) Kota Cirebon, Masyarakat yang memiliki Usaha Industri Rumah Tangga Pangan.

2. Data sekunder / teoritik

Sumber ini diperoleh dari buku atau pustaka serta literatur lainnya yang berhubungan dengan pokok permasalahan dampak perilaku ekonomi masyarakat terhadap ganti rugi pengadaan tanah tol cipali untuk kepentingan umum. Penelitian kepustakaan adalah penelitian dengan cara membaca dan mempelajari datadata tertulis yang berupa kitab perundang-undangan, buku-buku, majalah-majalah, makalah-makalah, kliping, dan surat kabar-surat kabar yang berkaitan dengan permasalahan yang akan diteliti.

\section{Teknik Pengumpulan Data}

Dalam pengumpulan data, penulis menggunakan cara sebagai berikut.

1. Wawancara

Wawancara merupakan suatu proses interaksi dan komunikasi semacam percakapan yang bertujuan untuk memperoleh informasi. Dalam penelitian ini wawancara dilakukan langsung dengan Majelis Ulama Indonesia Kota Cirebon, Dinas Perdagangan Koperasi Usaha Kecil dan Menengah Kota Cirebon, Dinas Kesehatan Kota Cirebon serta para Pemilik Industri Kecil Menengah (IKM). 
2. Dokumentasi

Dokumentasi yaitu data-data yang diperoleh dari dokumen-dokumen yang ada di Kantor Majelis Ulama Indonesia Kota Cirebon, Dinas Perdagangan Koperasi Usaha Kecil dan Menengah Kota Cirebon, Dinas Kesehatan Kota Cirebon serta para Pemilik Industri Kecil Menengah (IKM).

3. Kepustakaan

Kepustakaan yaitu teknik pengumpulan data untuk mencari konsep-konsep yang ada relevansinya dengan topik pembahasan yang akan dteliti yakni internet, brosur, bukubuku, dan dokumen lainnya yang ada di Dinas Perdagangan dan perindustrian Kota Cirebon.

\section{Teknik Penentuan Sampel}

Penentuan sampel dilakukan dengan teknik non random sampling, yaitu tidak memberikan kesempatan yang sama kepada setiap individu untuk menjadi anggota sampel. Bentuk metode non random sampling yang akan dipakai adalah "Purposive Sampling". Dalam purposive sampling ini "peneliti menggunakan pertimbangannya sendiri dengan bekal pengetahuan yang cukup tentang populasi untuk memilih anggota-anggota sampel". 3 Ukuran yang digunakan dalam penentuan sampel adalah klasifikasi jumlah skore variabel lemah suatu desa berdasarkan buku petunjuk penentuan desa yang diperoleh dari Kepala Dinas Perdagangan, Koperasi, Usaha Kecil dan Menengah Kota Cirebon, Kepala Dinas Kesehatan Kota Cirebon, Ketua Badan Penyelesaian Sengketa Konsumen (BPSK) Kota Cirebon, Majelis Ulama Indonesia Kota (MUI) Kota Cirebon, Masyarakat yang memiliki Usaha Industri Rumah Tangga Pangan.

Adapun cara menentukan populasi dan sampel adalah sebagai berikut:

${ }^{3}$ Lexy J. Moleong, Metodelogi Penelitian Kualitatif (Bandung: PT. Remaja Rosdakarya, 2013), 74.
1. Populasi adalah keseluruhan objek yang akan diteliti yaitu Perlindungan Konsumen Melalui Sertifikasi dan Label Halal atas Industri Rumah Tangga Pangan (IRTP) Mayarakat pemilik usaha Industri Rumah Tangga Pangan (IRTP) di Kota Cirebon.

2. Sampel adalah bagian dari kumpulan obyek penelitian yang dipelajari dan diamati. Sampel juga merupakan bagian dari populasi yang akan diteliti dan yang dianggap dapat menggambarkan populasi. Menurut Arikunto, untuk sekedar ancer-ancer maka apabila populasinya kurang dari 100, lebih baik diambil semua sehingga penelitiannya merupakan penelitian populasi, selanjutnya jika jumlah subjeknya lebih besar dapat diambil antara $10-15 \%$ atau 20-25\% atau lebih". Adapun sampel dalam penelitian ini menggunakan random sampling, yaitu $10 \%$ sehingga sampel yang diteliti sebanyak Masyarakat Pemilik Usaha Industri Rumah Tangga Pangan di Kota Cirebon.

Responden yang diharapkan dapat memberikan data yang dibutuhkan adalah sebagai berikut:

a. Kepala Dinas Perdagangan, Koperasi, Usaha Kecil dan Menengah Kota Cirebon.

b. Ketua Badan Penyelesaian Sengketa Konsumen (BPSK) Kota Cirebon.

c. Majelis Ulama Indonesia Kota (MUI) Kota Cirebon.

d. Masyarakat yang memiliki usaha Industri Rumah Tangga Pangan (IRTP) meliputi:
1) Pemilik Industri Kecil Menengah Brownies Kuping Cinta.
2) Pemilik Industri Kecil Menengah Tempe.
3) Pemilik Industri Kecil Menengah Susu Kedelai.
4) Pemilik Industri Kecil Menengah Kue




\section{Teknik Analisis Data}

Bahan-bahan yang diperoleh dari hasil penelitian tersebut, kemudian dikumpulkan dan diseleksi untuk diambil data khusus yang berkaitan dengan permasalahan yang akan dibahas, untuk mendapatkan gambaran umum tentang Perlindungan Konsumen melalui Sertifikasi dan Label halal atas Industri Rumah Tangga Pangan (IRTP). Data primer dari hasil wawancara yang dikumpulkan secara benar dan tepat. Setelah itu dihubungkan dengan data sekunder kemudian dianalisis. Sifat analisisnya adalah kualitatif, maksudnya disusun secara sistematis, logis, dan yuridis. Sedangkan penelitian ini bersifat deskriptif yaitu penelitian yang memaparkan dan bertujuan memberikan gambaran serta penjelasan dari variabel yang diteliti untuk mendapatkan gambaran umum tentang Perlindungan Konsumen melalui Sertifikasi dan Label Halal atas Industri Rumahtanggan Pangan (IRTP).

Teknik analisa data yang digunakan dalam penelitian ini adalah teknik analisa kualitatif dengan mengumpulkan data-data yang diperoleh kemudian dideskripsikan sehingga dapat memberikan gambaran umum tentang Perlindungan Konsumen melalui Sertifikasi dan Label Halal atas Industri Rumahtanggan Pangan (IRTP).

\section{KONSEP DASAR}

\section{Pengertian Konsumen}

Menurut Celina Tri Siwi Kristiyanti istilah konsumen berasal dari kata consumer (inggris-Amerika) atau consument (Belanda). ${ }^{4}$ Adapun menurut Abdul Halim Barkatulah, sebagaimana yang dikutip oleh Celina bahwa pengertian tersebut secara harfiah diartikan sebagai "orang atau perusahaan yang membeli barang tertentu atau menggunakan jasa tertentu" atau

${ }^{4}$ Cellina Tri Siwi Kristiyani, Hukum Perlindungan Konsumen (Jakarta: Sinar Grafika, 2009), 22. "sesuatu atau seseorang yang menggunakan suatu persediaan atau sejumlah barang". 5

Menurut Undang-Undang Nomor 8 Tahun 1999 Tentang Perlindungan Konsumen pasal 1 angka 2. Istilah konsumen juga dapat kita temukan dalam peraturan perundang-undangan Indonesia. Secara yuridis formal pengertian konsumen dimuat dalam Pasal 1 ayat 2 Undang Undang Nomor 8 Tahun 1999 tentang Perlindungan Konsumen, "konsumen adalah setiap orang pemakai barang atau jasa yang tersedia dalam masyarakat, baik bagi kepentingan diri sendiri, keluarga, orang lain, maupun makhluk hidup lain dan tidak untuk diperdagangkan".

Pengertian perlindungan konsumen dalam kamus besar Bahas Indonesia Perlindungan berasal dari kata lindung yang memiliki arti mengayomi, mencegah, mempertahankan, dan membentengi. Sedangkan Perlindungan berarti konservasi, pemeliharaan, dan penjagaan. Pengertian Perlindungan adalah tempat berlindung, hal (perbuatan dan sebagainya) memperlindungi. ${ }^{6}$

Dalam Undang-Undang Nomor 23 Tahun 2004 adalah segala upaya yang ditujukan untuk memberikan rasa aman kepada korban yang dilakukan oleh pihak keluarga, advokat, lembaga sosial, kepolisian, kejaksaan, pengadilan, atau pihak lainnya baik sementara maupun berdasarkan penetapan pengadilan. Sedangkan perlindungan yang tertuang dalam Peraturan Pemerintah Nomor 2 Tahun 2002 adalah suatu bentuk pelayanan yang wajib dilaksanakan oleh aparat penegak hukum atau aparat keamanan untuk memberikan rasa aman baik fisik maupun mental, kepada korban dan saksi, dari ancaman, gangguan, teror, dan kekerasan dari pihak manapun yang diberikan pada

\footnotetext{
${ }^{5}$ Cellina Tri Siwi Kristiyani, Hukum Perlindungan Konsumen, 21.

${ }^{6}$ Muhammad Djakfar, Hukum Bisnis (Malang: UIN-Malang Press, 2009), 12.
} 
tahap penyelidikan, penyidikan, penuntutan, dan atau pemeriksaan di sidang pengadilan.

Dengan demikian perlindungan konsumen dapat disimpulkan bahwa segala upaya yang menjamin adanya kepastian hukum untuk memberikan perlindungan kepada konsumen. Pengertian konsumen adalah orang yang mengkonsumsi barang atau jasa yang tersedia dimasyarakat baik untuk digunakan sendiri ataupun oranglain dan tidak untuk diperdagangkan.

Menurut para ahli perlindungan didefinisikan sebagai berikut; pertama, Mochtar Kusumaatmaja hukum perlindungan konsumen adalah keseluruhan asas-asas dan kaidah-kaidah hukum yang mengatur dan melindungi konsumen dalam hubungan dan masalahnya dengan para penyedia barang dan/atau jasa konsumen. ${ }^{7}$

Kedua, Undang-Undang Nomor 8 Tahun 1999 tentang Perlindungan Konsumen yang dimaksud dengan perlindungan konsumen adalah segala upaya yang menjamin adanya kepastian hukum untuk memberi perlindungan kepada konsumen. Dan yang dimaksud dengan konsumen adalah setiap orang pemakai barang dan/atau jasa yang tersedia dalam masyarakat, baik bagi kepentingan diri sendiri, keluarga, orang lain, maupun makhluk hidup lain, dan tidak untuk diperdagangkan.

Dan ketiga, menurut Janus Sidabalok, ${ }^{8}$ perlindungan konsumen adalah perlindungan hukum yang diberikan kepada konsumen dalam usahanya memenuhi kebutuhannya dari hal-hal yang dapat merugikan konsumen itu sendiri.

Dari serangkaian paparan pengertian di atas, maka dapat disimpulkan bahwa perlndungan konsumen adalah suatu segala upaya yang menjamin adanya kepastian hukum untuk member perlindungan kepada

\footnotetext{
${ }^{7}$ Mochtar Kusumaatmaja, Asas dan Perlindungan Hukum (Jakarta: Sinar Grafika, 2009), 34.

${ }^{8}$ Janus Sidabalok, Hukum Perlindungan Konsumen di Indonesia (Bandung: PT Citra Aditya Bakti, 2006), 6.
}

konsumen. Dengan demikian dapat diartikan bahwa perlindungan konsumen mengandung aspek perlindungan hukum. Adapun materi yang mendapat perlindungan bukan hanya fisik investor selaku konsumen produk dan jasa investasi, melainkan juga pada hakhaknya yang bersifat abstrak. ${ }^{9}$ Hak-hak konsumen ini merupakan suatu bentuk cerminan kepentingan-kepentingan konsumen yang harus dilindungi dan dipenuhi dengan baik oleh para pelaku usaha. Oleh karena itu, jika berbicara tentang perlindungan konsumen berarti mempersoalkan jaminan atau kepastian tentang terpenuhinya hak-hak konsumen. ${ }^{10}$ Dengan kata lain, perlindungan konsumen itu sendiri sesungguhnya identik dengan perlindungan yang diberikan hukum kepada konsumen sekaligus haknya. Perlindungan konsumen meliputi perlindungan yang berawal dari kegiatan untuk mendapatkan barang dan jasa hingga akibat-akibat dari pemakaian barang dan jasa tersebut.

Di Indonesia, masalah perlindungan konsumen baru mulai terdengar pada tahun 1970-an. ${ }^{11}$ Ini terutama ditandai dengan lahirnya Yayasan Lembaga Konsumen Indonesia (YLKI) pada bulan Mei 1973, yang mempunyai Motto "Melindungi Konsumen, Menjaga Martabat Konsumen, dan Membantu Pemerintah". Setelah itu, suara-suara untuk memberdayakan konsumen secara gencar baik melali ceramah, seminar dan tulisan-tulisan. Puncaknya adalah lahirnya Undang-undang Nomor 8 Tahun 1999 tentang Perlindungan Konsumen.

\footnotetext{
${ }^{9}$ Samsul, Perlindungan Konsumen Kemungkinan Penerapan Tanggung Jawab Mutlak (Jakarta: Program Pascasarjana Fakultas Hukum Universitas, 2004), 47.

${ }^{10}$ Husni Syawali dan Neni Sri Imaniyati, Hukum Perlindungan Konsumen (Bandung: CV Mandar Maju, 2002), 55.

${ }^{11}$ Sudikno Mertokusumo, Mengenal Hukum Suatu Pengantar Undang-Undang Nomor 8 Tahun 1999 tentang Perlindungan Konsumen (Yogyakarta: Erlangga, 2003), 23.
} 
Menurut Janus Sidabalok ${ }^{12}$ Asas perlindungan konsumenn berdasarkan Undang-Undang Nomor 8 Tahun 1999 tentang Perlindungan Konsumen pasal 2, ada lima asas perlindungan konsumen.

1. Asas manfaat

Maksud asas ini adalah untuk mengamanatkan bahwa segala upaya dalam penyelenggaraan perlindungan konsumen harus memberikan manfaat sebesar-besarnya bagi kepentingan konsumen dan pelau usaha secara keseluruhan.

2. Asas keadilan

Asas ini dimaksudkan agar partisipasi seluruh rakyat bias diwujudkan secara maksimal dan memberikan kesempatan kepada konsumen dan pelaku usaha untuk memperoleh haknyadan melaksanakan kewajibannya secara adil.

3. Asas keseimbangan

Asas ini dimaksudkan memberikan keseimbangan antara kepentingan konsumen, pelaku usaha, dan pemerintah dalam arti material maupun spiritual.

4. Asas keamanan dan keselamatan konsumen

Asas ini dimaksudkan untuk memberikan jaminan atas keamanan dan keselamatan kepada konsumen dalam penggunaan, pemakaian, dan pemanfaatan barang atau jasa yang dikonsumsi atau digunakan.

5. Asas kepastian hukum

Menurut Janus Sidabalok Asas ini dimaksudkan agar baik pelaku usaha maupun konsumen menaati hukum dan memperoleh keadilan dalam penyelenggaraan perlindungan konsumen, serta Negara menjamin kepastian hukum. ${ }^{13}$

\footnotetext{
${ }^{12}$ Janus Sidabalok, Hukum Perlindungan Konsumen di Indonesia, 26-27.

${ }^{13}$ Janus Sidabalok, Hukum Perlindungan Konsumen di Indonesia, 72.
}

\section{Sertifikasi dan Label Halal}

Sertifikasi menurut Departemen Pendidikan Nasional adalah penyertifikatkan. Sedangkan kata halal berasal dari bahasa Arab yang berarti "melepaskan" dan "tidak terikat", secara etimologi halal berarti halhal yang boleh dan dapat dilakukan karena bebas atau tidak terikat dengan ketentuanketentuan yang melarangnya. Atau diartikan sebagai segala sesuatu yang bebas dari bahaya duniawi. Dari pengertian tersebut di atas dapat memberikan pemahaman tentang sertifikasi halal yang artinya fatwa tertulis MUI yang menyatakan kehalalan suatu produk sesuai dengan syariat islam melalui pemeriksaan yang terperinci oleh Lembaga Pengkajian Pangan Obat-obatan dan Kosmetika Majelis Ulama Indonesia (selanjutnya disingkat LP POM MUI). ${ }^{14}$

Setiap Pangan Olahan yang dibuat di dalam negeri atau yang diimpor untuk diperdagangkan dalam kemasan eceran wajib memilliki izin edar Undang-Undang Nomor 18 tahun 2012 Pasal 91; PP no. 28 tahun 2004 Pasal 42; Perka Badan POM RI No. Hk.03.1.5.12.11.09955 Tahun 2011 Tentang Pendaftaran Pangan Olahan.

$$
\text { Menurut UU Perlindungan }
$$

Konsumen Pasal 8 Undang-Undang Nomor 8 Tahun 1999 tentang Perlindungan Konsumen juga mengatur larangan bagi pelaku usaha untuk memproduksi barang tanpa mencantumkan label dan tanggal kedaluwarsa.

\section{Pengertian Pangan dan Pangan Kadaluarsa}

Hal yang dimaksud dengan pangan menurut Undang-Undang Nomor 7 Tahun 1996 tentang pangan yaitu segala sesuatu yang berasal dari sumber hayati dan air baik yang diolah maupun tidak diolah, yang diperuntukkan sebagai makanan atau minuman bagi konsumsi manusia, termasuk bahan tambahan pangan, bahan baku

\footnotetext{
${ }^{14} \mathrm{http}: / / \mathrm{www} . c l e r o b o . c o m / 2015 / 09 / \mathrm{tafsir} / \mathrm{ma}$ kanan-yang-halal-dan-baik-dalam-qs-al.html. Diakses pada tanggal 10 Agustus 2017.
} 
pangan, dan bahan lain yang digunakan dalam proses penyiapan, pengolahan, dan atau pembuatan makanan atau minuman. (Konsideran Undang-Undang Nomor 7 Tahun 1996 tentang Pangan). Sedangkan pangan olahan adalah makanan dan minuman hasil proses dengan cara atau metode tertentu dengan atau tanpa bahan tambahan. Dalam industri pangan digunakan berbagai bahan kimia, seperti pengawet, pemberi rasa, peningkat rasa, pewarna dan sebagainya. $^{15}$

Pengertian makanan dalam pasal 1 huruf (a) Peraturan Menteri Kesehatan nomor 180/MEN.KES/PER/IV/1985 tentang makanan kadaluwarsa yaitu : "Makanan adalah barang yang diwadahi dan diberi label, dan yang digunakan sebagai makanan dan minuman manusia, akan tetapi bukan obat".

Berdasarkan peraturan pemerintah nomor 28 tahun 2004 tentang Keamanan, Mutu dan Gizi pangan, pasal 45 ayat (1) antara lain diamanatkan bahwa Badan (dalam hal ini Badan POM RI) berwenang melakukan pengawasan keamanan, mutu dan gizi pangan olahan yang beredar. Sedangkan ayat (2) dan (3) mengamanatkan bahwa Badan POM berwenang untuk mengambil contoh pangan olahan yang beredar dan melakukan pengujian. ${ }^{16}$

\section{PEMBAHASAN DAN DISKUSI}

Bentuk Perlindungan Konsumen Melalui Sertifikasi dan Label halal atas Industri Rumah Tangga Pangan (IRTP) pada Dinas Perdagangan Koperasi Usaha Kecil dan Menengah kota Cirebon

Dinas Perdagangan Koperasi Usaha Kecil dan Menengah Kota Cirebon dan Dinas Kesehatan Kota Cirebon terhadap produsen barang dalam bentuk pangan dan Industri Kecil Menengah memberikan perlindungan

\footnotetext{
${ }^{15}$ Sihombing, Perilaku Konsumen dan Strategi Pemasaran (Jakarta: Gelora Aksara Pratama, 1996), 72.

${ }^{16}$ N.H.T. Siahaan, Hukum Konsumen Perlindungan Konsumen dan Tanggung Jawab Produk (Jakarta: Penerbit Panta Rei, 2005), 119.
}

kepada konsumen dalam bentuk perlindungannya adalah memberikan kesempatan kepada pemilik produsen barang dalam bentuk pangan dan Industri Kecil Menengah (IKM) untuk Produk Industri Rumah Tangga (PIRT) sebaiknya didaftarkan untuk memperoleh sertifikat halal agar konsumen merasa nyaman, aman dan selamat dalam mengkonsumsi barang ataupun jasa. Untuk memperoleh Sertifikat halal, terlebih dahulu harus membuat Sertifikat Produk Industri Rumah Tangga ke Dinas Kesehatan Kota Cirebon, ${ }^{17}$ yang meliputi tahapan sebagai berikut:

1. Mengisi formulir yang telah disediakan oleh Dinas Kesehatan Kota Cirebon.

2. Mengikuti Penyuluhan Keamanan Pangan.

3. Melakukan survey lokasi tempat usaha produksi pangan dan Industri Kecil Menengah (IKM).

4. Sertifikat Produk Industri Rumah Tangga (PIRT) dikeluarkan oleh Dinas Kesehatan dalam jangka waktu dalam keadaan normal 1-2 hari. Dalam praktiknya pengajuan Sertifikat Produk Industri Rumah Tangga (PIRT) selalu ada perbaikan sehingga Sertifikat Produk Industri Rumah Tangga (PIRT) baru dapat dikeluarkan dalam jangka waktu 2 minggu sampai 1 bulan.

Berdasarkan hasil wawancara pada Hari Rabu, 16 Agustus 2017 Heni Siti Fartika selaku seksi pelayanan kefarmasian alkes dan makanan minuman bahwa tujuan diadakannya tahapan dalam pengajuan Sertifikat Produk Industri Rumah Tangga (PIRT) adalah untuk memberikan keyakinan pada lembaga dinas kesehatan atas produksi pangan yang dibuat oleh produsen dan memberikan manfaat lebih luas kepada konsumen akan hieginitas produk pangan tersebut sesuai dengan hak-hak konsumen, sehingga konsumen merasa terlindungi,

\footnotetext{
${ }^{17}$ https://berandainovasi.com/sertifikasi-
} keamanan-pangan-bagi-industri-nasionalpentingkah/diunduh pada 10 Agustus 2017. 
nyaman, aman, selamat dalam mengkonsumsi barang dalam bentuk pangan. Konsumen yang merasa haknya dilanggar oleh produsen maka konsumen dapat menyelesaikannya melalui Badan Penyelesaian Sengketa Konsumen (BPSK) Kota Cirebon yang keberadaannya didasarkan pada Keputusan Menteri Perdagangan Republik Indonesia Nomor 1068/M-DAG/KEP/10/2015 tentang Pemberhentian dan Pengangkatan Anggota Badan Penyelesaian Sengketa Konsumen pada Pemerintah Kota Cirebon dengan susunan anggota Badan Penyelesaian Sengketa Konsumen pada Pemerintah Kota Cirebon Periode tahun 2015-2020:

I. Unsur Pemerintah

1. Chandra Bima Pramana, S.H., M.M sebagai Anggota

2. Edi Tohidi, S.E., M.M sebagai Anggota

3. Drs. Sumyoto sebagai Anggota

II. Unsur Konsumen

1. Nusyirwan Ilyas S.H. sebagai Anggota

2. Ir. Nono Jumpriatno, S.H sebagai Anggota

3. Iksan Setiadi, S.H sebagai Anggota

III. Unsur Pelaku Usaha

1. Jaenudin Umar, S.E., S.H., M.MKn
sebagai Anggota

2. Rusdi Santoso, S.H sebagai Anggota

3. Ito Trisbyakto, S.E sebagai Anggota

\section{Peran Dinas Perdagangan Koperasi Usaha Kecil dan Menengah Kota Cirebon dalam Sertifikasi dan Label Halal atas Industri Rumah Tangga Pangan (IRTP)}

Kedudukan, Tugas Pokok dan Fungsi Dinas Perdagangan Koperasi Usaha Kecil dan Menengah Kota Cirebon berdasarkan Peraturan Wali Kota Cirebon Nomor 60 Tahun 2016 tentang Kedudukan, Struktur Organisasi, Tugas dan Fungsi, serta Tata
Kerja Dinas Perdagangan, Koperasi, Usaha Kecil dan Menengah Kota Cirebon

1. Dinas Perdagangan, Koperasi, Usaha Kecil dan Menengah merupakan unsur pelaksana urusan pemerintahan di bidang perdagangan, koperasi, usaha kecil dan menengah, serta perindustrian.

2. Dinas Perdagangan, Koperasi, Usaha Kecil dan Menengah dipimpin oleh seorang Kepala Dinas yang berada di bawah dan bertanggung jawab kepada Wali Kota melalui Sekretaris Daerah.

3. Dinas Perdagangan, Koperasi, Usaha Kecil dan Menengah mempunyai tugas pokok membanyi Wali Kota melaksanakan Urusan Pemerintahan dan Tugas Pembantuan yang diberikan kepada Daerah di bidang perdagangan, koperasi, usaha kecil dan menengah, serta perindustrian.

Dalam menyelenggarakan tugas pokok sebagaimana dimaksud dalam Pasal 3, Dinas Perdagangan, Koperasi, Usaha Kecil dan Menengah mempunyai fungsi:Perumusan kebijakan pelaksanaan Urusan Pemerintahan dan Tugas Pembantuan yang diberikan kepada Daerah bidang perdagangan, koperasi, usaha kecil dan menengah, serta perindustrian;

1. Pelaksanaan Urusan Pemerintahan dan Tugas Pembantuan yang diberikan kepada Daerah bidang perdagangan, koperasi, usaha kecil dan menengah, serta perundustrian;

2. Pelaksanaan evaluasi dan pelaporan Urusan Pemerintahan dan Tugas Pembantuan yang diberikan kepada Daerah bidang perdagangan, koperasi, usaha kecil dan menengah, serta perindustrian;

3. Pelaksanaan administrasi dinas dalam pelaksanaan urusan pemerintahan bidang perdagangan, koperasi, usaha kecil dan menengah, serta perindustrian; dan

4. Pelaksanaan fungsi lain yang diberikan oleh Wali Kota terkait dengan tugas dan fungsinya. 
Selain itu, Dinas Perdagangan, Koperasi, Usaha kecil dan Menengah terdiri dari unsur-unsur:

1. Unsur pimpinan adalah Kepala Dinas;

2. Unsur staf adalah Sekretaris;

3. Pembantu unsur staf adalah Kepala Sub Bagian;

4. Usnur lini adalah Kepala Bidang;

5. Pembantu unsur lini adalah Kepala Seksi;

6. UPT; dan

7. Pelaksana teknis operasional dan/atau administrasi adalah kelompok jabatan fungsional dan jabatan pelaksana.

Adapun susunan organisasi dalam

Dinas Perdagangan, Koperasi, Usaha kecil dan Menengah, sebagai berikut:

1. Kepala Dinas;

2. Sekretariat, terdiri dari:

a. Sub Bagian Umum;

b. Sub Bagian Program dan Pelaporan; dan

c. Sub Bagian Keuangan.

3. Bidang Bina Perdagangan, terdiri dari:

a. Seksi Bina Usaha dan Sarana Perdagangan; dan

b. Seksi Pengembangan Eskpor

4. Bidang Kemetrologian, terdiri dari:

a. Seksi Pelayanan Tera dan Tera Ulang; dan

b. Seksi Bina Sumber Daya Manusia, Standarisasi dan Pengawasan Kemetrologian.

5. Bidang Koperasi dan Usaha Kecil dan Menengah, terdiri dari:

a. Seksi Koperasi; dan

b. Seksi Usaha Mikro Kecil dan Menengah.

6. Bidang Perindustrian, terdiri dari:

a. Seksi Industri Kimia, Agro dan Hasil Hutan; dan

b. Seksi Industri Logam, Mesin, Elektronika dan Aneka.

7. UPT; dan

8. Kelompok Jabatan Fungsional

Bagan Struktur Organisasi Dinas Perdagangan, Koperasi, Usaha kecil dan Menengah sebagaimana tercantum dalam
Lampiran, merupakan bagian yang tidak terpisahkan dari Peraturan Wali Kota ini.

Berdasarkan hasil wawancara dengan Rusman Sitohang ST pada Hari Rabu, 16 Agustus 2017 selaku fungsional penyuluh industri perdagangan dari Dinas Perdagangan Koperasi Usaha Kecil dan Menengah Kota Cirebon berperan:

1. Memfasilitasi Industri Kecil Menengah (IKM) dan masyarakat umum yang mempunyai usaha produksi pangan untuk merekrut Industri Kecil Menengah (IKM) di wilayah Kota Cirebon yang ingin memperoleh sertifikat halal secara gratis. Adapun, cara melakukan rekruitmen Industri Kecil Menengah (IKM) diantaranya terdapat tahapan sebagai berikut, yaitu:

a. Industri Kecil Menengah (IKM) membawa produk pangan yang akan dilakukan sertifikasi halal;

b. Melampirkan sertifikat Produk Industri Rumah Tangga Pangan (PIRTP);

c. Mendeskripsikan profil Industri Kecil Menengah (IKM); dan

d. Selanjutnya, Industri Kecil Menengah (IKM) yang sudah memenuhi persyaratan akan diseleksi oleh Dinas Perdagangan dan Perindustrian provinsi. Adapun jangka waktu pendaftarannya memakan waktu 2 bulan dan hasilnya terbit pada umumnya pada bulan Agustus atau September.

2. Peran Dinas Perdagangan Koperasi Usaha Kecil dan Menengah Kota Cirebon juga bereran dalam hal Industri Kecil Menengah (IKM) yang telah memperoleh sertifikat halal akan difasilitasi untuk diikutkan dalam pameran-pameran perdagangan baik skala daerah, nasional, maupun internasional.

3. Berperan menyalurkan bantuan gubernur kepada Industri Kecil Menengah (IKM) yang telah memiliki sertifikat halal dalam bentuk peralatan. 
4. Pembinaan bagi masyarakat yang mempunyai industri rumah tangga untuk memajukan usahanya sehingga dapat meningkatkan kesejahteraan.

Tujuan dari adanya pemberian sertifikat halal atas Industri Kecil Menengah (IKM) terhadap Produk Industri Rumah Tangga Pangan (PIRTP) adalah untuk memberikan pembinaan bagi masyarakat yang mempunyai industri rumah tangga untuk meningkatkan usahanya sehingga berpengaruh pada tingkat kesejahterannya.

Beberapa contoh Industri Kecil Menengah di Kota Cirebon adalah dalam bentuk 1) Olahan sirup; 2) Olahan dodol; 3) Olahan ikan laut; 4) Olahan tempe; dan 5) Pembuatan roti.

Hasil wawancara dengan Arif Budiman pada Hari Jum'at, 18 Agutsus 2017 selaku Pemilik Industri Kecil Menengah (IKM) dengan produk tempe mengatakan bahwa keikutsertaannya dalam pembuatan Industri Rumah Tangga Pangan (IRTP) dan sertifikat halal karena beberapa alasan diantaranya:

1. Agar produknya dapat diperdagangkan di swalayan/supermarket.

2. Untuk meningkatkan penjualan.

3. Untuk meyakinkan konsumen atas produk pangan yang dibuatnya sehingga konsumen merasa aman, nyaman dan selamat dalam mengkonsumsi produk pangan.

Dampak positif dilakukannya sertifikasi halal adalah dapat mendongkrak penjualan produk pangan sehingga dapat meningkatkan kesejahteraan, akan tetapi terdapat juga kekurangannya dalam pemberlakuan Sertifikat Produk Industri Rumah Tangga yang masa berlakunya 5 tahun sedangkan Sertifikat Halal masa berlakunya 2. Akan tetapi untuk perpanjangan sertifikat halal terdapat biaya administrasi sebesar Rp.3.000.000 hal ini dianggap terlalu mahal oleh pemilik Industri Kecil Menengah, sehingga untuk melakukan perpanjangan mereka berfikie dua kali.

\section{KESIMPULAN}

Berdasarkan hasil penelitian yang dilakukan, dapat diambil 2 (dua) macam kesimpulan, yaitu pertama, bentuk perlindungan konsumen melalui sertifikasi dan label halal atas Industri Rumah Tangga Pangan (IRTP) pada Dinas Perdagangan, Koperasi, Usaha Kecil dan Menengah Kota Cirebon melalui sertifikasi dan label halal adalah dengan dikeluarkannya Sertifikat Produksi Pangan Industri Rumuh Tangga yang dikeluarkan oleh Dinas Kesehatan Kota Cirebon. Sertifikat tersebut akan meyakinkan konsumen atas produksi pangan yang dikonsumsi, sehingga dapat meberikan keamanan dan keselamatan pada konsumen. Perlindungan Terhadap konsumen juga dapat diperoleh melalui Badan Penyelesaian Sengketa Konsumen (BPSK) Kota Cirebon apabila konsumen berkehendak untuk menyelesaikan sengketa konsumen.

Dan kedua, peran Dinas Perdagangan, Koperasi, Usaha Kecil dan Menengah Kota Cirebon dalam sertifikasi dan label halal atas industri rumah tangga pangan (IRTP) adalah memfasilitasi Industri Kecil Menengah (IKM) dan masyarakat umum yang mempunyai usaha produksi pangan untuk merekruit Industri Kecil Menengah (IKM) di wilayah Kota Cirebon yang berkeinginan memperoleh sertifikat halal secara gratis. Adapun, cara melakukan rekruitmen Industri Kecil Menengah (IKM) diantara terdapat tahapan sebagai berikut, yaitu Industri Kecil Menengah (IKM) membawa produk pangan yang akan dilakukan sertifikasi halal, melampirkan sertifikat Produk Industri Rumah Tangga Pangan (PIRTP), mendeskripsikan profil Industri Kecil Menengah (IKM), selanjutnya Industri Kecil Menengah (IKM) yang sudah memenuhi persyaratan akan diseleksi oleh Dinas Perdagangan dan Perindustrian provinsi Jawa Barat. Adapun jangka waktu pendaftaran Sertifikat halal selama 2 (dua) bulan dan hasilnya Sertifikat Halal terbit pada pada bulan Agustus atau September setiap tahunnya. Peran Dinas Perdagangan 
Koperasi Usaha Kecil dan Menengah Kota Cirebon juga dalam hal Industri Kecil Menengah (IKM) yang telah memperoleh Sertifikat halal akan difasilitasi untuk diikutkan dalam pameran-pameran perdagangan baik bersekala daerah, nasional, maupun internasional. Dan peran lain Dinas Perdagangan, Koperasi, Usaha Kecil dan Menengah Kota Cirebon menyalurkan bantuan gubernur kepada Industri Kecil Menengah (IKM) yang telah memiliki sertifikat halal dalam bentuk peralata-peralatan yang dibutuhkan oleh Industri Kecil Menengah (IKM) sehingga dapat meningkatkan produksinya dan berimbas kepada peningkatan kesejahteraannya.

\section{DAFTAR PUSTAKA}

Djakfar, Muhammad. Hukum Bisnis. Malang: UIN-Malang Press, 2009.

http://clearinghouse.pom.go.id/artikelpendaftaran-atau-sertifikasi-produkpangan.html diunduh pada 11 Agustus 2017.

http://www.clerobo.com/2015/09/tafsir/mak anan-yang-halal-dan-baik-dalam-qsal.html.

http://www.hukumonline.com/klinik/detail/c 13808/kaitan-antara-sertifikat-halaldengan-uupk diunduh pada hari Kamis, 10 Agustus 2017.

http://www.hukumonline.com/klinik/detail/1 t58e70b8cde9c5/aturanpencantuman-kandungan-gizi-dankomposisi-bahan-di-kemasanmakanan-ringan diunduh pada 11 Agustus 2017.

https://berandainovasi.com/sertifikasikeamanan-pangan-bagi-industrinasional-pentingkah/diunduh pada 10 Agustus 2017.

Kristiyanti, Cellina Tri Siwi. Hukum Perlindungan Konsumen. Jakarta: Sinar Grafika, 2009.

Kusumaatmaja, Mochtar. Asas dan Perlindungan Hukum. Jakarta: Sinar Grafika, 2009.
Mertokusumo, Sudikno. Mengenal Hukum Suatu Pengantar Undang-Undang Nomor 8 Tahun 1999 tentang Perlindungan Konsumen. Yogyakarta: Erlangga, 2003.

Miru, Ahmadi dan Sutarman Yodo, Prinsipprinsip Perlindungan Hukum bagi Konsumen di Indonesia (Jakarta: PT. Raja Grafindo Persada, 2011.

Moleong, Lexy J. Metodelogi Penelitian Kualitatif. Bandung: PT. Remaja Rosdakarya, 2013.

Nasution, A. Z. Pengantar Hukum Perlindungan Konsumen. Jakarta: PT. Daya Widya, 2000.

Konsumen dan Hukum, Cet. I. Jakarta: Pustaka Sinar Harapan, 1995.

Rajagukguk, Erman et al. Hukum Perlindungan Konsumen. Bandung: Mandar Maju, 2000.

Samsul. Perlindungan Konsumen Kemungkinan Penerapan Tanggung Jawab Mutlak. Jakarta: Program Pascasarjana Fakultas Hukum Universitas, 2004.

Shidarta. Hukum Perlindungan Konsumen Indonesia. Jakarta: Grasindo, 2000.

Siahaan, N.H.T. Hukum Konsumen Perlindungan Konsumen dan Tanggung Jawab Produk. Jakarta: Penerbit Panta Rei, 2005.

Sidabalok, Janus. Hukum Perlindungan Konsumen di Indonesia. Bandung: PT Citra Aditya Bakti, 2006.

Sihombing. Perilaku Konsumen dan Strategi Pemasaran. Jakarta: Gelora Aksara Pratama, 1996.

Syawali, Husni dan Neni Sri Imaniyati. Hukum Perlindungan Konsumen. Bandung: CV Mandar Maju, 2002.

www.halalmui.org diunduh pada 23 Februari 2017.

Yani, Ahmad dan Gunawan Wudjaya. Hukum Perlindungan Konsumen. Jakarta: Gramedia Pustaka Utama, 2000 . 